\title{
Growth Hormone and Craniofacial Tissues. An update
}

\author{
George Litsas*
}

Orthodontist 2, Venizelou Str. Kozani, Greece

\begin{abstract}
Growth hormone is an important regulator of bone homeostasis. In childhood, it determines the longitudinal bone growth, skeletal maturation, and acquisition of bone mass. In adulthood, it is necessary to maintain bone mass throughout life. Although an association between craniofacial and somatic development has been clearly established, craniofacial growth involves complex interactions of genes, hormones and environment. Moreover, as an anabolic hormone seems to have an important role in the regulation of bone remodeling, muscle enhancement and tooth development. In this paper the influence of growth hormone on oral tissues is reviewed.
\end{abstract}

Keywords: Growth Hormone, Insulin-Like Growth Factor-I, Growth Hormone Receptor.

\section{INTRODUCTION}

Growth hormone (GH)/insulin-like growth factor I (IGFI) axis influences normal bone metabolism, and is a major regulator of postnatal growth and development [1]. GH is secreted by the anterior pituitary gland and acts directly on tissues via specific GH receptors or indirectly via the production of insulin-like growth factor I (IGF-I). Metabolic agents and hormonal systems such as growth hormone/insulin-Like Growth Factor-I axis, have a strong influence on the metabolism of oral tissues particularly during the period of growth [2,3]. The process of bone modeling and remodeling is orchestrated by a constellation of local growth factors, cytokines, and systemic hormones of which $\mathrm{GH}$ and IGF-1 are key components [4].

The purpose of this study is to critically review the influence of Growth hormone/ Insulin-Like Growth Factor-I on oral tissues including the mandibular condyle. To find relevant articles, a Medline search from 1966 to March 2014 was conducted. The Medline search for English language articles was based on the key words 'growth hormone', 'insulin-Like Growth Factor-I', 'oral tissues' and 'mandibular condyle'. Bibliographies of related articles were assessed for relevant studies to identify additional published references.

\section{GH/IGF-I AXIS}

Growth hormone $(\mathrm{GH})$ is a 191-amino acid, 22-kDa polypeptide, that is synthesized and secreted by cells called somatotrophs in the anterior pituitary under the control of hypothalamus [1]. It has many actions in the body including the regulation of bone growth and metabolism [2-4]. GH has a pulsatile secretion with age-dependent concentrations characterised by low secretion in the prepubertal period, a rise at

*Address correspondence to this author at the Orthodontist 2, Venizelou Str. Kozani, Greece; Tel: +30 24610 40087; Fax: +30 24610 41075;

E-mail: info@orthodontics-clinic.gr puberty $(\approx 0.4-0.5 \mathrm{mg} / 24 \mathrm{~h})$, and a decrease in old age [4]. GH secretion is under the influence of additional hormonal signals such as sex steroids and thyroid hormone, whereas glucocorticoids inhibit its secretion [5, 6]. GH circulates bound to a liver synthesized GH-binding protein [7]. GH affects several tissues including liver, muscle, kidney, and bone [8]. Insulin-Like Growth Factor-I (IGF-I) is critical for promoting the protein anabolic effects of $\mathrm{GH}[4,5,8]$. The genes of the GH family are assigned to chromosome 17q23q24 [9].

The somatomedin theory $[1,10]$ introduces the concept that GH stimulates skeletal growth by stimulating InsulinLike Growth Factor-I (IGF-I) which, in turn, stimulates longitudinal bone growth in an endocrine manner. The somatomedin hypothesis was challenged by Isaksson et al., [11, 12] and Green and co-authors [13] who introduced the "dual effector theory". According to this theory [14-16] the two hormones act independently at different stages of endochondreal maturation and differentiation. GH was found to stimulate young preadipocytes, whereas IGF-I stimulated cells at a later stage of development (Fig. 1).

In support of a growth hormone direct effect, growth hormone receptor (GHR) has been detected in the hypertrophic zone of the cartilage that develops into a secondary ossification center $[17,18]$. GH exerts pleiotropic effects on growth and development through GHR. The GHR consists of extra-cellular Gh-binding domain, transmembrane domain, and an intracellular domain involved in signal transduction [19]. The GHR belongs to class I of the hematopoietin superfamily of cytokine receptors, which includes more than 30 members, among others prolactin, erythropoietin, and leptin [14, 15]. GHR gene located on chromosome 5p13.1-p12 and is $87 \mathrm{~Kb}$ long, with 10 exons encoding 620 amino acids [19, 20]. GHR and IGF-I receptors has been immunolocalized in the PDL, along the adjacent mineralized tissue surfaces as well as in the dental tissues. These appeared to be fibroblast-like, mononuclear cells [21]. 


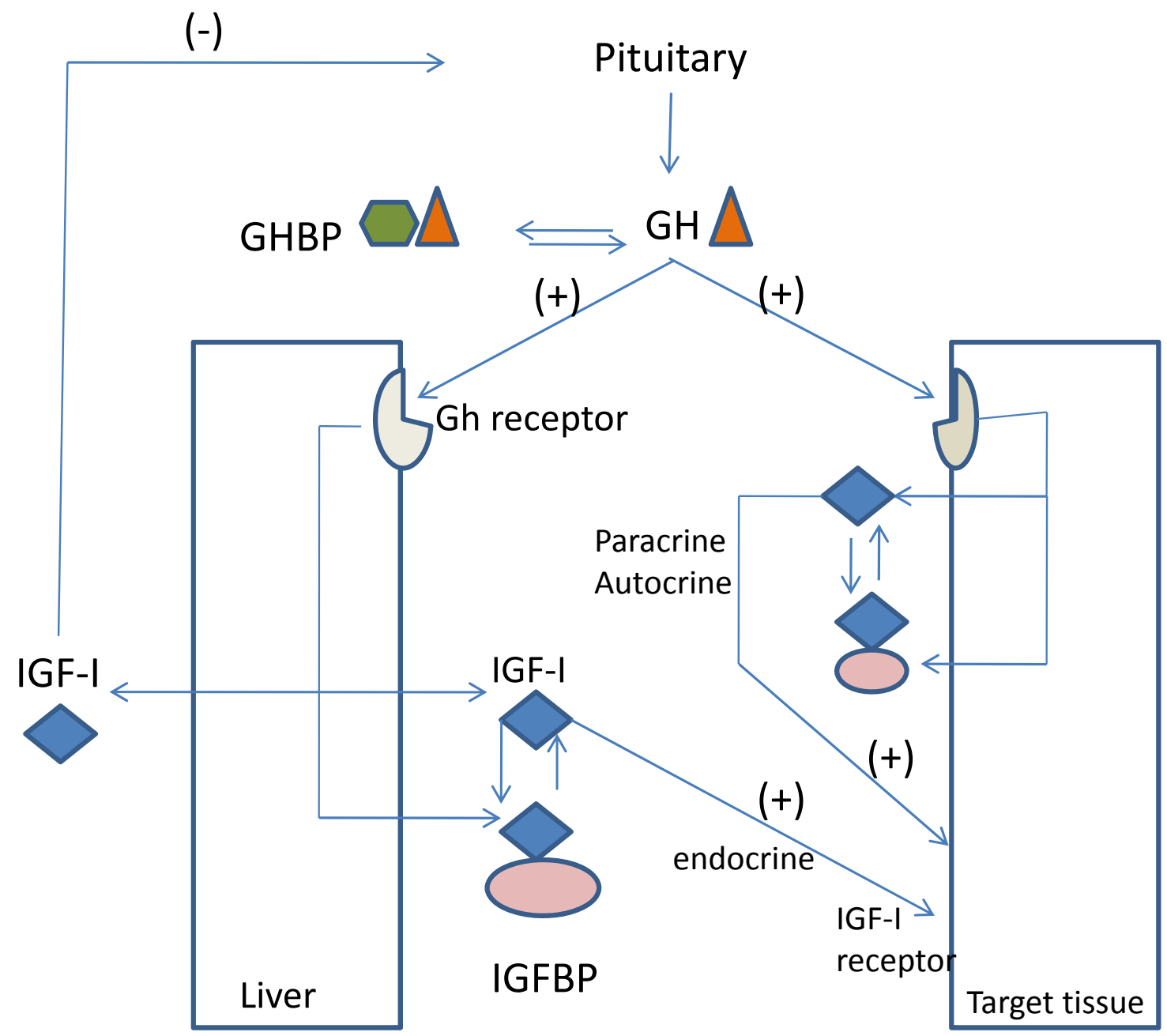

Fig. (1). The GH-IGF axis. Abbreviations are: ALS, acid labile subunit; GH, growth hormone; GHBP, GH binding protein; GHRH, GH releasing hormone; IGF, insulin-like growth factor; IGFBP, IGF binding protein.

\section{EFFECTS OF GH ON OSTEOBLASTS}

GH and IGF-I are anabolic hormones and have the potential to regulate bone modeling and remodeling. Growth factors that regulate local bone metabolism include growth hormone $(\mathrm{GH})$, insulin-like growth factor-I (IGF-I), epidermal growth factor (EGF) and interleukin-1 alpha (IL1alpha). GH stimulates the proliferation in a number of osteoblastic cell lines and primary isolated cells of various origins including human cells $[2,16,28]$. It seems to stimulate the proliferation, differentiation and the production of type I procollagen, osteocalcin and alkaline phosphatase in osteoblastic cells $[20,22]$. Furthermore, the osteoblasts responded to GH by expressing bone morphogenetic proteins (BMP) 2 and 4 [25]. BMPs that bind to surface receptors on progenitor and mature osteoblasts can trigger a signaling pathway that promotes osteoprogenitor cell differentiation and the upregulation of osteoblast activity, and periodontal ligament (PDL) cells.

The anabolic effects of IGFs on osteoblasts are modulated by several IGF binding proteins, mainly IGFBP-3, -4, and $-5[20,23]$. The stimulatory effect of IGF-I is increased by IGFBP- 3 and -5 , whereas it is decreased by the IGFBP- 4 [24]. It influences osteoblastic function in all stages of development and increases the replication of cells of the osteoblastic lineage [26, 27]. These proteins are believed to function in several ways: by enhancing the binding of IGF-I to its receptor, by decreasing the bioavailability of IGFI; by controlling the transport of the IGF to specific cell types thereby potentiating its activity in skeletal tissues; and by direct IGFI independent actions on target cells [21, 23]. One can assume that the GH and IGF-1 signaling pathways serve both independent and overlapping functions in the skeleton [25- 29] (Fig. 1).

Osteoblasts express also GHR, which is a member of the cytokine receptor superfamily [19, 23, 24]. IGFBPs regulate both the number and the activity of GHR through inhibition of IGF activity, recommending a local feedback of the GH/IGF axis at the tissue level by two possible mechanisms: i) liver and bone-derived IGF-I inhibits pituitary GH secretion, and ii) bone-derived IGF-I inhibits local action of GH by reducing GHR availability [20, 23, 25, 28]. It appears that some of the effects of $\mathrm{GH}$ on osteoblasts are mediated by IGFs, but others are not. 


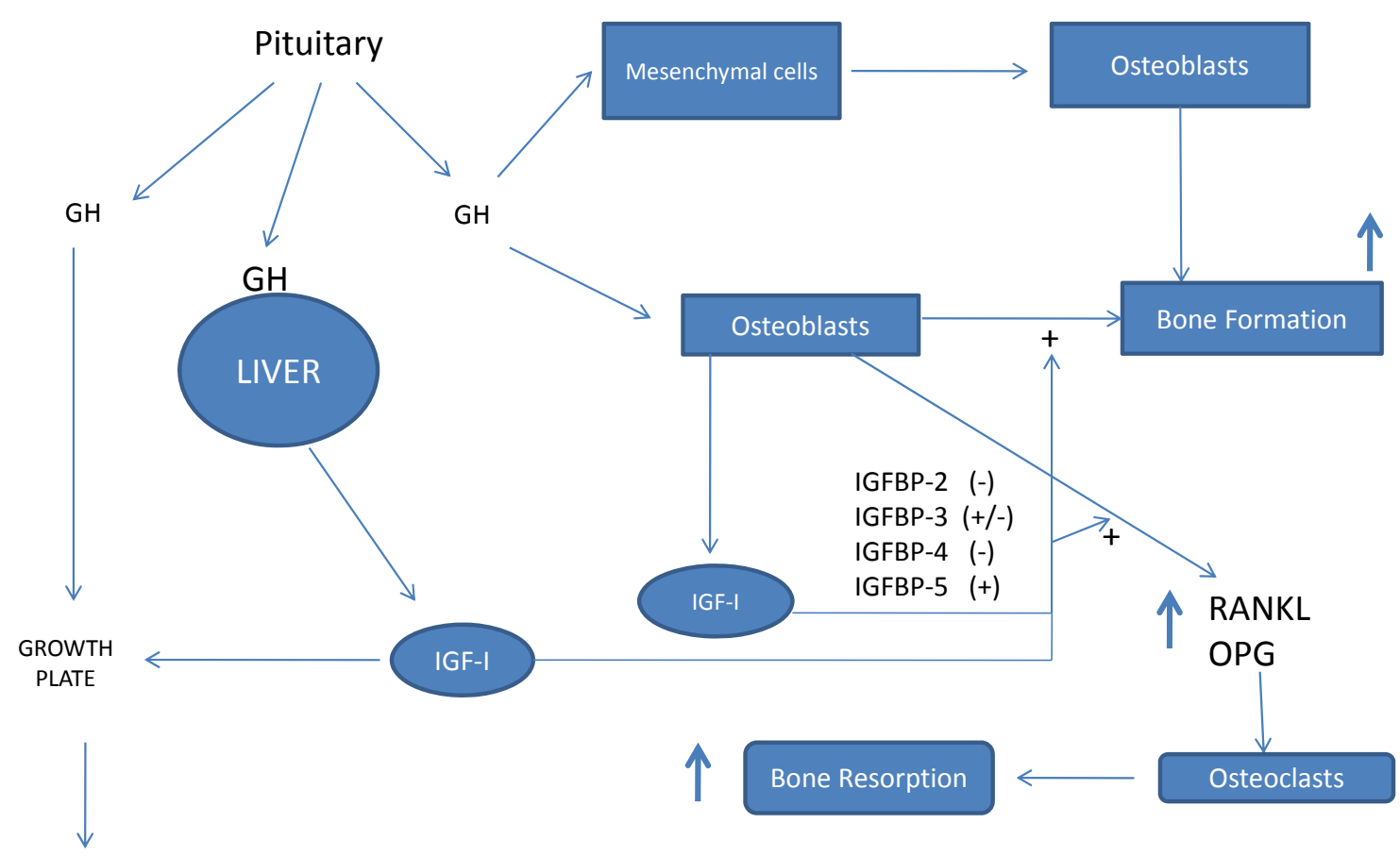

ENDOCHONDRAL OSSIFICATION

Fig. (2). Growth hormone and bone metabolism. GH, growth hormone; IGFBP, IGF binding protein.

\section{EFFECTS OF GH ON OSTEOCLASTS}

When GH stimulates bone formation, bone turnover is enhanced, thereby releasing molecules from activated marrow stromal cells and osteoblasts that also lead to enhanced osteoclastogenesis and mature osteoclast activity [29]. When either GH or IGF-I was added to bone cells, the formation as well as the resorption activity of osteoclast-like cells was increased [30]. GH stimulates osteoclastic bone resorption through both direct and indirect (IGF-I and IL-6) actions on osteoclast differentiation. It has been demonstrated that IGFI supports activation and formation of osteoclasts in cultures of unfractionated mouse bone cell [29], while human osteoclasts express functional IGF-I receptors [3]. During tooth eruption and tooth movement, alveolar bone osteoblasts and osteoclasts demonstrate GHR immunoreactivity. The greatest numbers of positive cells were located in the PDL space than on the mineralized tissues [29, 31] (Fig. 2).

\section{EFFECTS OF GH ON ALVEOLAR BONE AND ORAL MUSCLES}

Bone growth is a three-dimensional process and, as such, bone length and bone width naturally grow in proportion to each other. GH stimulates periosteal apposition through: i) the action of osteoblasts that add mineralized tissue on the outer (periosteal) bone surface, a process called periosteal apposition $[32,33]$ and ii) indirectly through the forces acting on bones by the muscles, itself being regulated by anabolic effects of GH and IGF-1 on muscle tissue.

GH exerts growth-promoting and metabolic effects in target tissues by binding to the transmembrane GHR and triggering enhanced GHR association with, and activation of the cytoplasmic tyrosine kinase JAK2 [9, 19]. Skeletal muscle cells respond rapidly to $\mathrm{GH}$ administration through increased tyrosine phosphorylation of the GHR [34]. GHR is required for normal skeletal muscle development. First, by regulating myoblast production of IGF-1, normal myofiber type specification, myonuclei accumulation, and expansion of myofiber diameter [35]. Second, promotes GH functions (independent of IGF-1) facilitating normal insulin action in skeletal muscle, which ultimately impacts global nutrient metabolism [36, 41]. It should be noticed also, that muscle mass accompanied by increasing muscle strength, preceded and exceeded any bone mass gain during GH therapy [3741]. Sotiropoulos et al., [41] has shown that GH signaling profoundly influenced muscle mass, predominantly by promoting fusion of myoblasts with nascent myotubes. Moreover, have shown that mice globally deficient in $\mathrm{GH}$ receptor have reduced muscle mass with defective myofiber specification and growth. Similar, the loss of anabolic GH/IGF-1 action on GHD individuals could affect muscle mass and muscle force and as a consequence the bone adaptation and the cortical thickness [42].

\section{EFFECTS OF GH ON MANDIBULAR CONDYLE}

The condylar cartilage in the mandible is a secondary type cartilage and it is unique among ossifying cartilages in the skeleton in that it is derived from cells of periosteal origin of the neural crest. Secondary cartilages are structurally distinct from limb growth plate and differ primarily in their superficial layers, which comprise a perichondrium in which prechondroblastic cells secrete a type I collagen rather than 
type II secreted by chondrocytes [43, 44]. In mandibular condyle, chondrogenesis is activated when the external stimuli, e.g., condylar repositioning, generate the differentiation of mesenchymal cells in the articular layer of cartilage into chondrocytes, which proliferate and then progressively mature into hypertrophic cells [45].

Molecular genetic analysis has shown that both GHR and IGF-I receptors are present in the chondroprogenitor and chondroblast layers of the mandibular condyle [46]. The local production of IGF-I is parallel to the distribution of IGF-I receptors, whereas the action of GH on this cartilage appears to be IGF-I dependent [47]. Under GH excess, local IGF-I synthesis is stimulated; the mitotic activity and the mature cells of the mandibular cartilage are increased, leading to more endochondral ossification [48, 49]. Conversely, a lack of GH decreases mitotic activity through less IGF-I synthesis, leading to less endochondral ossification [50].

Idiopathic short stature and Laron syndrome is caused by the dominant-negative defects of the intracellular domain of GHR, and affected individuals have smaller facial measurements too, including the length of the mandible [51]. The relationship between craniofacial morphology and GHR mutations (P56IT variant) was studied in normal adult Japanese males and females. At position 1777 in GHR, a transversion of amino acid from cytosine to adenine changed codon 561 from proline to threonine (P561T), affecting the cytoplasmic domain of the GHR [52]. Individuals without P56IT had a significantly greater mandibular ramus length than did those with P56IT. This suggests that the GHR gene P56IT variant may be associated with mandibular height growth and can be a genetic marker for it. When the relationship between craniofacial morphology and single-nucleotide polymorphisms (SNPs) in GHR were investigated in Chinese Han individuals [53], patients with a genomic polymorphism at codon 526 (I526L) of the GHR gene had a greater mandibular ramus length than the control group. Tomoyasu et al., [54] analyzed 5 single-nucleotide polymorphisms (SNPs) of the GHR in Japanese population found an association between P561T, $\mathrm{C} 422 \mathrm{~F}$ and mandibular ramus height. However, they couldn't report a correlation between the I526L polymorphism of the GHR and mandibular ramus height like Chinese Han individuals. Similar are the results in the Korean population [55]. In addition, the effect of P561T heterozygous mutation on children with and without mandibular protrusion was investigated in Japanese children [56]. The mandibular linear parameters tended to be smaller in subjects carrying the heterozygous mutation, suggested that P561T variant functions as an inhibitory factor in the process of mandibular growth.

\section{EFFECTS OF GH ON TOOTH TISSUES}

The development of the dentition is an integral part of craniofacial growth, even though it is not closely related to general growth. At the cellular level, the differentiation of odontoblasts from the neural crest cells is a long process comparable with the process of osteoblast differentiation. $\mathrm{GH}$ is known to increase the formation of bone and hard tissues of the tooth (dentine, cementum, and enamel), as do bone morphogenetic proteins [25]. GH receptors are expressed in these tissues and could mediate local growth responses. This is found in the distal cytoplasm of the future amelodentinal junction [58]. Moreover, IGF-I receptors has been demonstrated in the early stages of rat molar tooth bud development in vivo [57]. Thus, GH may be the major regulator at IGF-I expression in the early stages of tooth development.

The effects of $\mathrm{GH}$ on odontogenic epithelial cells were investigated on the growing root tip of the incisors of 8 Lewis dwarf rats- four of them treated by GH $(66 \mu \mathrm{g} / 100 \mathrm{gr}$ body/wt) compare to 4 normal Lewis rats [57]. Significantly fewer odontogenic epithelia were found in dwarf rats, but in treated dwarf rats the numbers of nuclei in the internal enamel epithelium, stratum intermedium, and Hertwig root sheath were equivalent to normal rats. GH seems to increase cell proliferation of both the inner dental epithelium (IDE), dental papilla, as well as, in Hertwig's Epithelial Root Sheath (HERS) determining the root dimensions. They speculated that the epithelial stem cells are targets for $\mathrm{GH}$ as a mitogenic. The GH mitogenic stimulus is mediated through epidermal growth factor (EGF) which acts as a GH-dependent mitogenic. An alternative mechanism may lie in some feedback mechanism resulting from differentiation. Thus, if $\mathrm{GH}$ promotes the odontogenic cells to differentiate, feedback would induce the stem cells to divide to maintain the pipeline.

Similarly, in order to evaluate the effects of GH and IGFI on odontogenesis in early bell stage, recombinant hGH (50 or $100 \mathrm{ng} / \mathrm{ml})$, IGF-I (100 or $200 \mathrm{ng} / \mathrm{ml}$ ) or fatal calf serum were added to the media of 16-day old, fetal mouse's first molar tooth germs [58]. The GH-treated tooth germs had increased mitotic indices and higher cell densities in the dental papillae, while the greatest extent of differentiation and the higher volumetric changes were observed on IGF-Itreated germs. Moreover, GH and IGF-I induce production of morphogenetic protein 2 and 4 (BMP-2, BMP-4) and Transforming Growth Factor-beta superfamily, affecting the odontoblast differentiation as well as dentine formation. Growth hormone can be detected as early as the cap stage within the dental papilla. However, the undifferentiated dental mesenchymal cells of the dental papilla, up until the cap stage, showed very weak amount for GH receptor. The same is true for the IGF-I receptors. It seems that GH and IGF-I on the proliferation of the odontogenic mesenchyme is similar to that postulated for cartilage and bone i.e. that both are mitogenic, but that $\mathrm{GH}$ primes a small proportion of preodontoblasts which then become IGF-I sensitive. This suggests that the effect of $\mathrm{GH}$ on dentine growth in dwarf rats is to produce a larger population of odontoblasts subsequently active in dentine matrix deposition [59].

The effect of GH status on the cellular cementum as well as on the tooth shape and size was investigated in decalcified first mandibular molars of GH-excess, dwarf and GHreceptor-knockout mice $[60,61]$. Cellular cementum reduced nearly 10 times in GH receptor-knockout mice, three times in $\mathrm{GH}$ antagonist mice, and increased twice in giant mice [60]. Moreover, morphometric analysis of 10 linear dentin 
matrix dimensions revealed that Dwarf animals showed smaller crown, shorter and smaller dentin roots and mesiodistal width at the cementoenamel junction (CEJ) axis. Interestingly, even if GH-excess models had longer roots, neither the mesio-distal crown width nor the root dentin thickness was affected by the $\mathrm{GH}$ excess [62].

Moreover, dental maturation has shown to be consistently delayed in GHD children, although to a lesser degree than skeletal maturation. Microdontia, missing third molars, smaller premolar crowns, and partial eruption of the permanent dentition as well as delayed dental age have been reported [63-68]. In idiopathic short stature children and GHD patients, GH administration helps to normalize skeletal growth but dental development is not significantly affected [67]. One the other hand, Krekmanova et al., showed an acceleration of dental maturity after 2 years GH therapy in GHD child [66].

\section{DISCUSSION}

Both modeling and remodeling are distinct physiologic responses to integrated mechanical and metabolic demands. $\mathrm{GH}$ acts directly on osteoblasts to stimulate bone formation whereas stimulate osteoclastic bone resorption too, through its direct action on the maturation of osteoclast precursor cells and through its indirect activation of mature osteoclasts, possibly via stromal cells [30]. Markers of bone metabolism, including serum alkaline phosphatase, procollagen 1 carboxylterminal propeptide, and deoxypyridinoline, increased significantly by GH administration [71]. Finally, GH powder application around dental implants placed immediately after tooth extraction enhances bone density and collagen fibers $[72,73]$.

Most experimental orthodontics studies have shown that 10-14 days are required for one complete bone remodelling cycle to take place [21]. The peak in bone resorption on the compression side occurs 7 days after orthodontic force application appliance activation. The amount of GH receptors was transiently decline in the compressed PDL area during the first three days. The initial depression of the amount of GHR is the result of the trauma of the orthodontic force application. However, the gradual increase in GHR immunoreactivity at days 7 and 14 (peak osteoclastic activity) suggests that cells have an altered function, possibly undergoing differentiation and proliferation [29]. Rh-Gh application on the periodontic cells can improve the recovery of pathologic changes caused by the orthodontic forces [74]. Orthodontic tooth movement seems to produce tissue reactions that are associated not only with local factors related to teeth and occlusion, but also with systemic factors related to bone metabolism $[69,70]$.

Furthermore, GH/IGF-I axis influences the loadingrelated bone formation modulating the responsiveness of bone tissue to mechanical stimuli by changing thresholds for bone formation [71-75]. Cortical bone formation rate and cancellous bone volume increases when bone is reloaded and IGF-I is added [76]. GH/IGF-I axis interacts with sex steroids in periosteal apposition challenging the traditional concept of androgen- stimulatory and estrogen-inhibitory effects on periosteal expansion [77].
$\mathrm{GH}$ affects muscle tissues too, which regulate cortical bone geometry [38]. Muscle enlargement is accompanied by increasing muscle strength leading to secondary adaptive bone gain [37]. Growth of the facial bones such as maxilla and mandible occurs partly from direct remodeling of the surfaces of the bone. Normal muscle development and function is a prerequisite for normal bone adaptation and enlargement. Administration of $\mathrm{GH}$ regulates muscle mitochondrial function by increasing the levels of several key mitochondrial proteins, and by switching fuel utilization toward fat oxidation [78]. In GHD not only the muscle weight is reduced, but also the myosin chain isoform and fiber type distribution is changed resulting in a deficit of periosteal bone formation [79]. Similar mechanisms in the craniofacial area could be account for the much reduced growth rate of facial bones in GHD individuals compared to normal one [49]. GH through periosteal apposition and muscular growth seems to play an important role in facial growth and development $[33,35,38]$.

The condylar cartilage has quite a different embryologic origin than the cartilage of the cranial base synchondroses or the epiphyses of the long bones. In young individuals it displays some functional characteristics of both a growth plate and an articular cartilage [43]. The adaptive remodeling of condylar cartilage proceeds with the biomolecular pathway initiating from chondrogenesis and finalizing with osteogenesis. While condylar cartilage from the young animals responded only slightly to $\mathrm{GH}[47,48]$ a significant response was observed on cartilage from the old animals [80]. It seems that at a later age, when the chondroblasts are no longer dividing in the condylar cartilage, the undifferentiated cells constitute the target of $\mathrm{GH}$, similar to the condition in long bone epiphyseal cartilage [11, 15]. The increased Knowledge of the germinal cells that proliferate in mandibular condyle, as well as, the effects of growth factors, is promising application to clinical treatment in the near future.

The process of tooth formation is quite similar to that of bone formation. Dental mesenchyme cells differentiate into odontoblasts, which produce and secrete collagenous and non-collagenous matrix protein during dentin formation. $\mathrm{GH}$ is able to induce proliferation of epithelial stem cells in molar buds, along with preameloblast differentiation and dentine matrix formation [57]. Growth hormone, GHR and its binding protein are detectable during tooth bud formation at the embryonic cap and bell stages provoked morphodifferentiation, and dentinogenesis [81]. GH through morphogenetic protein 2 and 4 (BMP-2, BMP-4) and growth factor-b superfamily, effect the odontoblast differentiation as well as dentine and enamel formation [82] Inhibition of BMP-4 expression because of GH deficiency results in loss of tooth crown morphology [67].

The effect of GH supplementation on craniofacial growth has been studied in children with idiopathic short stature (ISS) or GHD and those born small for gestational age (SGA), as well as in children with syndromes or hypopituitary deficiency [49, 67, 82-84]. These children have small facial height and width, small head circumference, immature small face, protruding frontal bones, saddle nose and convex profile. Most cephalometric studies demonstrated short ramus height as well as small linear dimensions in the poste- 
rior cranial base and mandibular and maxillary lengths. Furthermore, the cranial base angle and gonial angle as well as the angle between the maxillary and mandibular planes are larger than normal. It seems that structures maturing more rapidly are more susceptible to the influence of external factors like GHD than more slowly maturing structures [85].

Despite the relatively widespread use of GH to augment stature, the effects of this practice on the growth of the craniofacial complex have not been extensively investigated. The greater increases in growth in the mandibular length (ramus, not the corpus) and posterior face height indicate that the interstitial cartilage growth of the condyles and spheno-occipital synchondrosis are influenced more by GH treatment than the periosteal and sutural growth sites $[67,83$, $84,86,87]$. As a general rule, the earlier the GH administration, the larger were the positive effects on craniofacial structures such as the posterior cranial base. Most studies have suggested delaying orthodontic treatment because GH therapy can cause unpredictable mandibular growth [88].

\section{CONCLUSION}

GH/IGF-I axis seems to elicit varying responses in craniofacial region. It plays a major role in regulating growth during childhood and adolescence and also regulates metabolism through its binding to the growth hormone transmembrane receptor. It especially affects growth sites with endochondral ossification, such as the condylar cartilage and the cranial base. It has the potential to regulate odontogenesis, bone modeling and remodelling, exerting its anabolic effects on both trabecular and cortical bone. Although the understanding of the role of the $\mathrm{GH}$ in craniofacial tissues has increased enormously in recent years, there are still lots of things which need to be the subject of research studies.

\section{CONFLICT OF INTEREST}

The author confirms that this article content has no conflict of interest.

\section{ACKNOWLEDGEMENTS}

None declared

\section{ABBREVIATIONS}

$$
\begin{aligned}
\text { GH } & =\text { Growth Hormone, } \\
\text { GHD } & =\text { Growth Hormone Deficiency, } \\
\text { GHR } & =\text { Growth Hormone Receptor, } \\
\text { IGF-I } & \text { Insulin-Like Growth Factor-I, } \\
\text { IGFBP } & =\text { IGF binding proteins. }
\end{aligned}
$$

\section{REFERENCES}

[1] Giustina A, Veldhuis JD. Pathophysiology of the neuroregulation of growth hormone secretion in experimental animals and the human. Endocr Rev 1998; 19: 717-97.

[2] Slootweg MC. Growth hormone and bone. Horm Metab Res 1993; 25: 335-43.
Wuster C. Growth hormone and bone metabolism. Acta Endocrinol (Copenh) 1993; (Suppl 2): 14-8.

[4] Giustina A, Mazziotti G, Canalis E. Growth hormone, insulin-like growth factors, and the skeleton. Endocr Rev 2008; 29: 535-59.

[5] Giustina A, Wehrenberg WB. The role of glucocorticoids in the regulation of growth hormone secretion. Trends Endocrinol Metab 1992; 3: 306-11.

[6] Giustina A, Wehrenberg WB. Influence of thyroid hormones on the regulation of growth hormone secretion. Eur J Endocrinol 1995; 133: 646-53.

[7] Ballesteros M, Leung KC, Ross RJ, Iismaa TP, Ho KK. Distribution and abundance of messenger ribonucleic acid for growth hormone receptor isoforms in human tissues. J Clin Endocrinol Metab 2000; 85: 2865-871.

[8] Feld S, Hirschberg R. Growth hormone, the insulin-like growth factor system, and the kidney. Kidney Int 1995; 48: 45-1.

[9] Chen EY, Liao Y-C, Smith DH, Barrera-Saldana HA, Gelinas RE, Seeburg PH. The human growth hormone locus: Nucleotide sequence, biology, and evolution. Genomics 1989; 4: 479-97.

[10] Daughaday WH, Hall K, Raben MS, et al. Somatomedin: Proposed designation for sulphation factor. Nature 1972; 235: 107.

[11] Isaksson OG, Jansson JO, Gause IA. Growth hormone stimulates longitudinal bone growth directly. Science 1982; 216:1237-9.

[12] Isaksson OG, Lindahl A, Nilsson A, Isgaard J. Mechanism of the stimulatory effect of growth hormone on longitudinal bone growth. Endocr Rev 1987; 8: 426-38.

[13] Green H, Morikawa M, Nixon T. A dual effector theory of growthhormone action. Differentiation 1985; 29: 195-8.

[14] Barnard R, Haynes KM, Werther GA, Waters MJ. The odontogeny of growth hormone receptors in the rabbit tibia. Endocrinology 1988; 122: 2562-9.

[15] Barnard R, Ng KW, Martin TJ, Waters MJ. Growth hormone receptors in clonal osteoblast-like cells mediate a mitogenic response to GH. Endocrinology 1991; 128: 1459-64.

[16] Kassem M, Blum W, Ristelli J, Mosekilde L, Eriksen EF. Growth hormone stimulates proliferation and differentiation of normal human osteoblast-like cells in vitro. Calcif Tissue Int 1993; 52: 222-6.

[17] Gevers EF, van der Eerden BC, Karperien M, Raap AK, Robinson IC, Wit JM. Localization and regulation of the growth hormone receptor and growth hormone binding protein in the rat growth plate. J Bone Miner Res 2002; 17: 1408-19.

[18] Werther GA, Haynes K, Edmonson S, Oakes S, Buchanan CJ. Identification of growth hormone receptors on human growth plate chondrocytes. Acta Paediatr 1993; 82: 50-3.

[19] Leung DW, Spencer SA, Cachianes G, et al. Growth hormone receptor and serum binding protein: Purification, cloning and expression. Nature 1987; 330: 537-43.

[20] Hogan BL. Bone morphogenic proteins: Multifunctional regulators of vertebrate development. Genes Dev 1996; 10: 1580-94.

[21] Ong CK, Joseph BK, Waters MJ, Symons AL. Growth hormone receptor and IGF-I receptor immunoreactivity during orthodontic tooth movement in the prednisolone-treated rat. Angle Orthod 2001; 71(6): 486-93.

[22] Hayden JM, Mohan S, Baylink DJ. The insulin-like growth factor system and the coupling of formation to resorption. Bone 1995; 17(Suppl 2): 93S-8S.

[23] Tsuji K, Bandyopadhyay A, Harfe BD, et al. BMP2 activity, although dispensable for bone formation, is required for the initiation of fracture healing. Nat Genet 2006; 38: 1424-9.

[24] Ernst M, Rodan GA. Increased activity of insulin-like growth factor (IGF) in osteoblastic cells in the presence of growth hormone (GH): positive correlation with the presence of the GH-induced IGF-binding protein BP-3. Endocrinology 1990; 127: 807-14.

[25] Li H, Bartold PM, Young WG, Xiao Y, Waters MJ. Growth hormone induces bone morphogenetic proteins and bone-related proteins in the developing rat periodontium. J Bone Miner Res 2001; 16(6): 1068-76.

[26] Ohlsson C, Bengtsson BA, Isaksson OGP, Andreassen TT, Slootweg MC. Growth hormone and bone. Endocr Rev 1998; 19: 55-79. Lofqvist C, Andersson E, Gelander L, Rosberg S, Blum WF, Albertsson-Wikland K. Reference values for IGF-I throughout childhood and adolescence: A model that accounts simultaneously for the effect of gender, age and puberty. J Clin Endocrinol Metab 2001; 86: 5870-6.

[28] Ueland T, Odgren PR, Yndestad A, et al. Growth hormone substitution increases gene expression of members of the IGF family in 
cortical bone from women with adult onset growth hormone deficiency: Relationship with bone turn-over. Bone 2003; 33: 638-45.

[29] Tengku BS, Joseph BK, Harbrow D, Taverne AAR, Symons AL. Effect of a static magnetic field on orthodontic tooth movement in the rat. Eur J Orthod 2000; 22: 475-87.

[30] Nishiyama K, Sugimoto T, Kaji H, Kanatani M, Kobayashi T, Chihara K. Stimulatory effect of growth hormone on bone resorption and osteoclast differentiation. Endocrinology 1996; 137: 3541.

[31] Symons AL. Reduced growth hormone receptor immunoreactivity in osteoclasts adjacent to the erupting molar in the incisor-absent (osteopetrotic) rat. Eur J Oral Sci 2003; 111: 503-9.

[32] Zhang CZ, Young WG, Li H, Clayden AM, Garcia- Aragon J, Waters MJ. Expression of growth hormone receptor by immunocytochemistry in rat molar root formation and alveolar bone remodeling. Calcif Tissue Int 1992; 50:541-6.

[33] Baron R. General principles of bone biology. In: Favus MJ, Ed. Primer on the metabolic bone diseases and disorders of mineral metabolism. $5^{\text {th }}$ ed. Washington DC: American Society for Bone and Mineral Research 2003: pp. 1-8.

[34] Sadowski CL, Wheeler TT, Wang LH, Sadowski HB. Regulation of IGF-I and suppressor of cytokine signaling gene expression in C2C12 skeletal muscle cells. Endocrinology 2001; 142: 3890-900.

[35] Daugaard JR, Brabnert M, Manhem P, et al. Effect of 6 months of $\mathrm{GH}$ treatment on myosin heavy chain composition in GH-deficient patients. Eur J Endocrinol 1999; 141: 342-9.

[36] Mavalli MD, DiGirolamo DJ, Fan Y, et al. Distinct growth hormone receptor signaling modes regulate skeletal muscle development and insulin sensitivity in mice. J Clin Invest 2010; 120: 400720.

[37] Koranyi J, Svensson J, Gotherstrom G, Sunnerghahen KS. Baseline characteristics and the effects of five years of $\mathrm{GH}$ replacement therapy in adults with GH deficiency of childhood or adulthood onset: A comparative, prospective study. J Clin Endocrinol Metab 2001; 86: 4693-9.

[38] Gotherstrom G, Elbornsson, M, Stibrant-Sunnerhagen K, Bengtsson BA, Johannsson J, Svensson J. Ten years of growth hormone $(\mathrm{GH})$ replacement normalizes muscle strength in GH-deficient adults. J Clin Endocrinol Metab 2009; 94: 809-16.

[39] Gosteli-Peter MA, Winterhalter KH, Schmid C, Froesch ER, Zapf J. Expression and regulation of insulin-like growth factor-I (IGF-I) and IGF-binding protein messenger ribonucleic acid levels in tissues of hypophysectomized rats infused with IGF-I and growth hormone. Endocrinology 1994; 135: 2558-67.

[40] Lupu F, Terwilliger JD, Lee K, Segre GV, Efstratiadis A. Roles of growth hormone and insulin-like growth factor 1 in mouse postnatal growth. Dev Biol 2001; 229: 141-62.

[41] Sotiropoulos A, Ohanna M, Kedzia C, et al. Growth hormone promotes skeletal muscle cell fusion independent of insulin-like growth factor 1 up-regulation. Proc Natl Acad Sci USA 2006; 103 : 7315-20

[42] Frost HM. On the estrogen-bone relationship and postmenopausal bone loss: A new model. J Bone Miner Res 1999; 14: 1473-7.

[43] Petrovic AG, Stutzmann JJ, Oudet CL. Control processes in the postnatal growth of the condylar cartilage of the mandible. In: McNamara Jr. JA, Ed. Determinants of mandibular form and growth. Ann Arbor: Center for Human Growth and Development, University of Michigan 1975; pp. 101-54.

[44] Solem RC, Eames BF, Tokita M, Schneider RA. Mesenchymal and mechanical mechanisms of secondary cartilage induction. Dev Biol 2011; 356: 28-39.

[45] Silbermman M, Reddi AH, Hand AR, Leapman RD, Von der Mark, Franzen A. Further characterisation of the extracellular matrix in the mandibular condyle in neonatal mice. J Anat 1987; 151: 169-88.

[46] Lewinson D, Bialik GM, Hochberg Z. Differential effects of hypothyroidism on the cartilage and the osteogenic process in the mandibular condyle: Recovery by growth hormone and thyroxine. Endocrinology 1994; 135: 1504-10.

[47] Visnapuu V, Peltomäki T, Rönning O, Vahlberg T, Helenius H. Growth hormone and Insulin-like growth factor I receptors in the temporomandibular joint of the rat. J Dent Res 2001; 80: 1903-7.

[48] Maor G, Hochberg Z, Von der Mark K, Heinegard D, Silbermann M. Human growth hormone enhances chondrogenesis and osteogenesis in a tissue culture system of chondroprogenitor cells. Endocrinology 1989; 125: 1239-45.
[49] Pirinen S, Majurin A, Lenko HL Koski K. Craniofacial features in patients with deficient and excessive growth hormone. J Craniofac Genet Dev Biol 1994; 14: 144-52.

[50] Ramirez-Yañez GO, Young WG, Daley TJ, Waters MJ. Influence of growth hormone on the mandibular condylar cartilage of rats. Arch Oral Biol 2004; 49: 585-90.

[51] Laron Z. Laron syndrome (primary growth hormone resistance or insensitivity): The personal experience 1958 - 2003. J Clin Endocrinol Metab 2004; 89: 1031-44.

[52] Yamaguchi T, Maki K, Shibasaki Y. Growth hormone receptor gene variant and mandibular height in the normal Japanese population. Am J Orthod Dentofacial Orthop 2001; 119: 650-3.

[53] Zhou J, Lu Y, Gao XH, et al. The growth hormone receptor gene is associated with mandibular height in a Chinese population. J Dent Res 2005; 84: 1052-6.

[54] Tomoyasu Y, Yamaguchi T, Tajima A, Nakajima T, Inoue I, Maki $\mathrm{K}$. Further evidence for an association between mandibular height and the growth hormone receptor gene in a Japanese population. Am J Orthod Dentofacial Orthop 2009; 136: 536-41.

[55] Kang EH, Yamaguchi T, Tajima A, et al. Association of the growth hormone receptor gene polymorphisms with mandibular height in a Korean population. Arch Oral Biol 2009; 54: 556-62.

[56] Sasaki Y, Satoh K, Hayasaki H, Fukumoto S, Fujiwara T, Nonaka $\mathrm{K}$. The P561T polymorphism of the growth hormone receptor gene has an inhibitory effect on mandibular growth in young children. Eur J Orthod 2009; 31: 536-41.

[57] Young WG, Zhang CZ Li H, Osborne P, Waters MJ. The influence of growth hormone on cell proliferation in odontogenic epithelia by bromodeoxyuridine immunocytochemistry and morphometry in the Lewis dwarf rat. J Dent Res 1992; 71: 1807-11.

[58] Zhang CZ, Li H, Young WG, Bartold PM, Chen C, Waters MJ Evidence for a local action of growth hormone in embryonic tooth development in the rat. Growth Fact 1997; 14: 131-43.

[59] Young WG, Rush JV, Stevens MR, et al. Comparison of the effects of growth hormone, insulin like factor-I and fetal calf serum on mouse molar odontogenesis in vitro. Arch Oral Biol 1995; 40: 78999.

[60] Tabata MJ, Fujii T, Liu JG, et al. Bone morphogenetic protein 4 is involved in cusp formation in molar tooth germ of mice. Eur $\mathrm{J}$ Oral Sci 2002; 110: 114-21

[61] Smid JR, Rowland JE, Young WG, et al. Mouse cellular cementum is highly dependent on growth hormone status. J Dent Res 2004; 83: 35-9.

[62] Smid JR, Rowland JE, Young WG, Coschigano KT, Kopchick JJ, Waters MJ. Mouse molar dentin size/shape is dependent on growth hormone status. J Dent Res 2007; 86: 463-8.

[63] Sarnat H, Kaplan I, Petzelan A, Laron Z. Comparison of dental findings in patients with isolated growth hormone deficiency treated with human growth hormone $(\mathrm{hGH})$ and in untreated patients with Laron-type dwarfism. Oral Surg Oral Med Oral Pathol 1988; 66: 581-6.

[64] Bigeard L, Sommermater J. Retard dentaire et microdonfii chez I'enfant atteint de deficit en hormone somatotrope. J Biol Bucc 1991; 19: 291-6.

[65] Krekmanova L, Bronnegard M, Marcus C, Grondahl E, Modeer T, Dahloff G. Dental maturity in children of short stature, with or without growth hormone deficiency. Eur J Oral Sci 1997; 105: 5516.

[66] Krekmanova L, Carlstedt-Duke C, Marcus C, Dahloff G. Dental maturity in children of short stature--a two-year longitudinal study of growth hormone substitution. Acta Odont Scand 1999; 57: 93-6.

[67] Kjellberg H, Beiring M, Albertsson Wikland K. Craniofacial morphology, dental occlusion, tooth eruption, and dental maturity in boys of short stature with or without growth hormone deficiency. Eur J Oral Sci 2000; 108: 359-67.

[68] Ito RK, Vig KW, Garn SM, et al. The influence of growth hormone $(\mathrm{rhGH})$ therapy on tooth formation in idiopathic short statured children. Am J Orthod Dentofacial Orthop 1993; 103: 358-64.

[69] Schweizer R, Martin DD, Schwarze CP, et al. Cortical bone density is normal in prepubertal children with growth hormone deficiency, but initially decreases during $\mathrm{GH}$ replacement due to early bone remodeling. J Clin Endocrinol Metab 2003; 88: 5266-72.

[70] Iglesias L, Yeh JK, Castro Magana M, Aloia JF. Effects of growth hormone on bone modeling and remodeling in hypophysectomized young female rats: A bone histomorphometric study. J Bone Miner Metab 2001; 29: 159-67. 
[71] Baroncelli GI, Saggese G. Effect of GH treatment on bone mass in children with GH deficiency. J Endocrinol Invest 2005; 10: 23-7.

[72] Eldein HAM, Elghamrawy SH, Osman SM, Elhak AR. Histological evaluation of the effect of using growth hormone around immediate dental implants in fresh extraction sockets: An experimental study. Implant Dent 2011; 20(1): 47-55.

[73] Calvo-Guirado JL, Mate-Sanchez J, Delgado-Ruiz R, RamirezFernández MP, Cutando-Soriano A, Peña M. Effects of growth hormone on initial bone formation around dental implants: A dog study. Clin Oral Implants Res. 2011; 22(6): 587-93.

[74] Zhang J1, Wang SL, Wang XX, Huang Y, Zhang WJ. Effects of rh-GH on the remodeling of periodontium in the ovariectomized rats after orthodontic tooth movement. Shanghai Kou Qiang Yi Xue 2006; 15: 521-5.

[75] Forwood MR, Li L, Kelly WL, Bennett MB. Growth hormone is permissive for skeletal adaptation to mechanical loading. J Bone Miner Res 2001; 16: 2284-90.

[76] Boudignon BM, Bikle DD, Kurimoto P, et al. Insulin-like growth factor I stimulates recovery of bone lost after a period of skeletal unloading. J Appl Phys 2007; 103: 125-31.

[77] Vanderschueren D, Venken K, Ophoff J, Bouillon R, Boonen S. Clinical Review: Sex steroids and the periosteum—reconsidering the roles of androgens and estrogens in periosteal expansion. J Clin Endocrinol Metab 2006; 91: 378-82.

[78] Short KR, Moller N, Bigelow ML, Coenen-Schimke J, Nair KS. Enhancement of muscle mitochondrial function by growth hormone. J Clin Endocrinol Metab 2008; 93(2): 597-604.

[79] Everitt AV, Terry V, Phillips MJ, Kerry HM, Shorey CD. Morphometric analysis of gastrocnemius muscle fiber size and fiber proportions in the hypophysectomized rat after prolonged admini- stration of growth hormone or thyroxine. Growth Dev Aging 1996; 60: 85-93.

[80] Livne E, Laufer D, Blumenfeld I. Comparison of in vitro response to growth hormone by chondrocytes from mandibular condyle cartilage of young and old mice. Calcif Tissue Int 1997; 61: 62-7.

[81] Thesleff I, Keranen S, Jernvall J. Enamel Knots as signaling centers linking tooth morphogenesis and odontoblast differentiation. Adv Dent Res 2001; 15: 14-8.

[82] Vainio S, Karavanova I, Jowett A, Thesleff I. Identification of BMP-4 as a signal mediating secondary induction beteen epithelial and mesenchymal tissues during early tooth development. Cell 1993; 75: 45-58.

[83] Van Erum R, Mulier M, Carels C, Verbeke G, de Zegher F. Craniofacial growth in short children born small for gestational age: Effect of growth hormone treatment. J Dent Res 1997a; 76: 1579-86.

[84] Van Erum R, Carels C, Verbeke G, de Zegher F. Craniofacial growth in short children born small for gestational age: Two years follow-up after high-dose growth hormone treatment. J Craniofac Genet Dev Biol 1997; 17: 184-9.

[85] Litsas G. Growth hormone therapy and craniofacial bones: A comprehensive review. Oral Dis 2013; 19: 559-67.

[86] Kjellberg H, Wikland KA. A longitudinal study of craniofacial growth in idiopathic short stature and growth hormone-deficient boys treated with growth hormone. Eur J Orthod 2007; 29: 243-50.

[87] Funatsu M, Sato K, Mitani H. Effects of growth hormone on craniofacial growth. Angle Orthod 2006; 76: 970-7.

[88] Hwang CJ, Cha JY. Orthodontic treatment with growth hormone therapy in a girl of short stature. Am J Orthod Dentofacial Orthop 2004; 126: 118-26.

Received: November 04, $2014 \quad$ Revised: December 08, 2014

Accepted: December 11, 2014

(C) George Litsas; Licensee Bentham Open.

This is an open access article licensed under the terms of the Creative Commons Attribution Non-Commercial License (http://creativecommons.org/licenses/by-nc/3.0/) which permits unrestricted, non-commercial use, distribution and reproduction in any medium, provided the work is properly cited. 